\title{
IbM Pendampingan Penggunaan Sistem Ujian Online Kepada Guru-guru MA Al Hadi Mranggen
}

\author{
Defri Kurniawan ${ }^{1}$, Danang Wahyu Utomo ${ }^{2}$, Ramadhan Rakhmat Sani ${ }^{3}$ \\ ${ }_{1,2,3}$ Universitas Dian Nuswantoro, \\ Fakultas Ilmu Komputer; \\ J1. Imam Bonjol 207 \\ $\underline{1}$ defri.kurniawan@dsn.dinus.ac.id, $\stackrel{2}{2}$ danang.wu@dsn.dinus.ac.id, \\ ramadhan_rs@dsn.dinus.ac.id
}

\begin{abstract}
Abstrak
Pelaksanaan Ujian Nasional di Indonesia telah menggunakan komputerisasi guna menggantikan sistem yang lama yaitu ujian nasional menggunakan kertas dan pensil. Adanya ujian nasional berbasis komputer, memberikan keuntungan dalam hal efisiensi waktu, biaya, mengurangi kecurangan, dan mempercepat proses evaluasi. Madrasah Aliyah Al Hadi yang berada di desa Banyumeneng, Kecamatan Mranggen, Demak merupakan sekolah yang telah menyelenggarakan Ujian Nasional Berbasis Komputer (UNBK). Namun berdasarkan Rekap Hasil Ujian Nasional (UN) Tingkat Sekolah tahun pelajaran 2017/2018 ketiga Program Studi pada Madrasah Aliyah Al Hadi masih masuk pada kategori Kurang. Kurangnya nilai UN siswa pada beberapa Program Studi tersebut, dapat disebabkan oleh kurangnya siswa dalam berlatih (try out) mengerjakan soal-soal UN dengan menggunakan komputer. Paperless Test System merupakan sistem yang dikembangkan dari penelitian untuk mengevaluasi hasil belajar siswa, dengan memberikan test yang dikerjakan secara online dengan batas waktu tertentu. Ketrampilan dalam pembuatan bank soal diberikan kepada guru-guru MA Al Hadi pada pelatihan penggunaan aplikasi Paperless Test System. Hasil pelatihan menunjukkan guru-guru MA Al Hadi menjadi lebih mengenal dan memahami penggunaan sistem ujian tanpa kertas sebagai media evaluasi hasil belajar siswa.
\end{abstract}

Kata kunci-Sistem Ujian Online, Try Out, Ujian Nasional, Madrasah Aliyah Al Hadi

\begin{abstract}
The implementation of the National Examination in Indonesia has used computerization to replace the old system, namely the national exam using paper and pencil. The existence of computer-based national exams provides benefits in terms of time efficiency, costs, reducing fraud, and accelerating the evaluation process. Madrasah Aliyah Al Hadi in Banyumeneng Village, Mranggen District, Demak is a school that has organized a Computer-Based National Examination (UNBK). However, based on the National Examination Results (UN) of the 2017/2018 school year, the third Study Program in Al Hadi Islamic Senior High School is still in the Less category. The lack of student UN scores in some of the Study Programs, can be caused by a lack of students in practice (try out) working on national exam questions using a computer. Paperless Test System is a system developed from research to evaluate student learning outcomes, by giving tests done online with a certain time limit. Skills in making a question bank are given to MA Al Hadi teachers in training on the use of the Paperless Test System application. The results of the training showed that MA Al Hadi teachers became more
\end{abstract}


familiar with and understood the use of a paperless examination system as a medium for evaluating student learning outcomes.

Keywords - Online Test System, Try Out, National Examination, Madrasah Aliyah Al Hadi

\section{PENDAHULUAN}

Adanya kemajuan di bidang teknologi informasi dapat memberikan dampak bagi dunia pendidikan. Dampak yang dihasikan salah satunya adalah adanya perubahan pada sistem pendidikan yang melibatkan teknologi informasi. Komputer saat ini telah digunakan sebagai media dalam pelaksanaan ujian yang dikenal dengan Computer Based Test (CBT) yang diimplementasikan di Indonesia sebagai Ujian Nasional Berbasis Komputer (UNBK) [1]. Penerapan ujian nasional dengan menggunakan komputer menjadi tantangan tersendiri bagi tiap sekolah di seluruh wilayah Indonesia. Setiap sekolah akan berusaha untuk dapat memberikan dukungan infrastruktur yang terbaik guna lancarnya proses pengerjaan ujian nasional. Penggunaan komputer sebagai media untuk ujian nasional memiliki keuntungan antara lain dapat menghemat anggaran sehingga tidak perlu biaya dalam mencetak naskah ujian, kemudahan dalam pengiriman, dapat tersebar ke seluruh wilayah, kecepatan memperoleh hasil ujian, dan jika diperlukan dapat dicetaknya sertifikat setelah peserta menyelesaikan ujian [2]. Selain itu keunggulan lainnya dari ujian menggunakan komputer yaitu dapat dikuranginya resiko kecurangan siswa dan pihak tertentu serta menjadikan pengawasan lebih mudah [3]. Sehingga penggunaan komputer sebagai media untuk ujian nasional merupakan model yang tepat dalam menggantikan model sistem ujian sebelumnya yaitu dengan menggunakan pensil dan kertas.

Madrasah Aliyah (MA) Al Hadi merupakan sekolah yang beralamat di Girikusuma RT 02 RW 03, desa Banyumeneng, kecamatan Mranggen, Kabupaten Demak merupakan salah satu tempat warga dusun Girikusuma, desa Banyumeneng dan wilayah kabupaten Demak untuk memperoleh pendidikan. Berdasarkan data siswa tingkat XI Madrasah Aliyah Al Hadi pada tahun pelajaran 2016/2017 sebanyak 103 dari 132 siswa berasal dari kabupaten Demak. Hampir setengahnya berasal dari desa Banyumeneng, yaitu sebanyak 60 siswa (45\%) dari desa Banyumeneng dan sisanya dari luar desa Banyumeng sebanyak 72 siswa (55\%). Madrasah Aliyah Al Hadi merupakan harapan bagi masyarakat di desa Banyumeneng dan sekitarnya untuk mendapatkan hasil belajar yang baik. Namun besarnya harapan warga desa Banyumeneng dan sekitarnya pada hasil belajar yang baik belum sesuai dengan realita yang ada. Rekap Hasil Ujian Nasional (UN) Tingkat Sekolah pada tahun pelajaran 2017/2018 pada Madrasah Aliyah Al Hadi untuk program studi IPA memiliki rata-rata nilai 53,70, program studi IPS memiliki rata-rata nilai 48,63, sedangkan program studi Keagamaan memiliki rata-rata nilai 50,93 [4]. Ketiga Program Studi tersebut masih masuk pada kategori Kurang. Kurangnya nilai UN siswa pada beberapa Program Studi tersebut, dapat disebabkan oleh kurangnya siswa dalam berlatih (try out) mengerjakan soal-soal UN dengan menggunakan komputer.

Try Out merupakan kegiatan yang dilakukan oleh pihak sekolah dan terkait untuk melakukan evaluasi dalam mempersiapkan dan membiasakan siswa dalam menghadapi ujian nasional [5]. Bagi siswa yang bersekolah dengan infrastruktur (laboratorium komputer) yang memadai, tentu tidak ada masalah dalam proses belajar mengajar 
maupun dalam menjawab soal-saol test menggunakan komputer. Namun, bagi siswa yang bersekolah tanpa infrastruktur yang memadai akan menjadi masalah utama yaitu siswa bingung dalam menggunakan komputer dalam menjawab soal-soal ujian. Penelitian [6] menunjukkan bahwa try out memiliki korelasi yang positif dan signifikan terhadap hasil ujian nasional, sehingga semakin tinggi hasil pada try out maka hasil nilai ujian nasional akan mengikuti. Maka untuk itu, perlunya sekolah dalam hal ini Madrasah Aliyah Al Hadi untuk dapat menyelenggarakan try out dengan media komputer sehingga hasil belajar siswa dapat dievaluasi dan ditingkatkan.

Pelaksanaan try out secara mandiri di sekolah diperlukan persiapan baik dari segi infrastruktur maupun aplikasi yang digunakan. Paperless Test System merupakan aplikasi hasil karya tim peneliti Udinus dalam mengembangkan sistem ujian tanpa kertas yang digunakan untuk berlatih mengerjakan soal-soal ujian secara online [7][8]. Namun untuk dapat berlatih mengerjakan soal-soal ujian menggunakan komputer, perlu disiapkannya bank soal oleh guru-guru pengampu mata pelajaran sehingga dapat digunakan oleh siswa untuk berlatih. Pada kegiatan pengabdian kepada masyarakat (abdimas) di Madrasah Aliyah Al Hadi, tim abdimas memberikan program Ipteks bagi Masyarakat (IbM) dalam menggunakan aplikasi Paperless Test System kepada guruguru untuk membuat dan mengelola soal serta membuat kategori soal atau pokok bahasan. Adanya program IbM ini diharapkan dapat memberikan solusi bagi mitra yaitu Madrasah Aliyah Al Hadi untuk dapat meningkatkan nilai ujian nasionalnya.

\section{METODE PENELITIAN}

Pelaksanaan IbM penggunaan aplikasi Paperless Test System untuk guru-guru Madrasah Aliyah Al Hadi memiliki beberapa tahapan kegiatan. Tahapan kegiatan yang dilaksanakan dimulai dari Pengumpulan Data, Persiapan Teknis, Pelaksanaan dan Evaluasi.
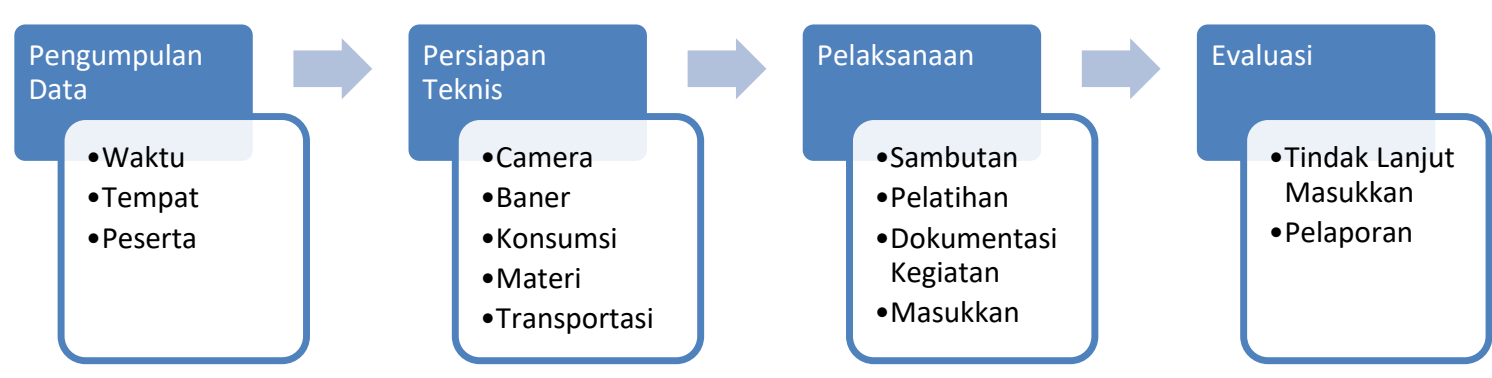

Gambar 1. Tahapan Kegiatan IbM

Adapun langkah-langkah kongkrit terhadap tahapan kegiatan program IbM dari pengumpulan data sampai dengan evaluasi diuraikan sebagai berikut:

1. Koordinasi dengan pihak Madrasah Aliyah Al Hadi yang terdiri dari Kepala Madrasah dan Wakil Kepala Madrasah Bidang Kurikulum untuk menentukan teknis pelaksanaan pengabdian dan,

2. Penentuan jumlah guru peserta pelatihan (undangan), waktu dan tempat pelaksanaan pelatihan.

3. Penyebaran undangan pelatihan ke guru-guru Madrasah Aliyah Al Hadi.

4. Pembentukan tim dan pembagian tugas anggota tim pengabdian masyarakat 
5. Persiapan teknis pelaksanaan bersifat fisik antara lain: komputer, LCD projector, peralatan dokumentasi, backdrop, konsumsi, materi pelatihan (printed), kuisioner, dan daftar hadir peserta.

6. Persiapan teknis pelaksanaan bersifat non-fisik antara lain: aplikasi sistem ujian, materi presentasi pelatihan (soft-copy), dan koneksi internet.

7. Pelaksanaan kegiatan pengabdian masyarakat dan dokumentasi kegiatan.

8. Pengumpulan dokumentasi dan pembuatan jurnal abdimas.

9. Penyusunan laporan pertanggungjawaban kegiatan.

10. Pembubaran tim dan evaluasi kegiatan pengabdian masyarakat

\section{HASIL DAN PEMBAHASAN}

Kegiatan Ipteks bagi Masyarakat (IbM) dapat diselenggarakan atas kerjasama Tim Pengabdian Universitas Dian Nuswantoro (UDINUS) dengan Madrasah Aliyah (MA) Al Hadi, Girikusuma, Mranggen yang telah berkomitmen sebagai mitra. Walaupun pelaksanaan IbM memiliki keterbatasan waktu dan tempat disebabkan pihak mitra sedang mempersiapkan Ujian Nasional, namun kegiatan dapat tetap berjalan.

Aplikasi Paperless Test System yang digunakan untuk kegiatan IbM memiliki fungsi sistem dan operasi dasar sebagai seperti disajikan pada tabel di bawah ini.

Tabel 1 Fungsi Sistem dan Operasi Dasar Aplikasi Paperless Test System

\begin{tabular}{|c|c|c|}
\hline ID & Fungsi Sistem & Operasi Dasar \\
\hline FS-01 & Melakukan Pengelolaan Kelas & $\begin{array}{l}\text { Menambah, mengubah, } \\
\text { menghapus Kelas }\end{array}$ \\
\hline FS-02 & Melakukan Pengelolaan Siswa & $\begin{array}{l}\text { Menambah, mengubah, } \\
\text { menghapus Siswa }\end{array}$ \\
\hline FS-03 & Melakukan Pengelolaan Guru & $\begin{array}{l}\text { Menambah, mengubah, } \\
\text { menghapus Guru }\end{array}$ \\
\hline FS-04 & $\begin{array}{l}\text { Melakukan Pengelolaan Mata } \\
\text { Pelajaran (Mapel) }\end{array}$ & $\begin{array}{l}\text { Menambah, mengubah, } \\
\text { menghapus Mapel }\end{array}$ \\
\hline FS-05 & $\begin{array}{l}\text { Melakukan Pengelolaan } \\
\text { Pokok Bahasan }\end{array}$ & $\begin{array}{l}\text { Menambah, mengubah, } \\
\text { menghapus Pokok Bahasan }\end{array}$ \\
\hline KF-06 & $\begin{array}{l}\text { Membuat Soal dan Jawaban } \\
\text { Test }\end{array}$ & $\begin{array}{l}\text { Menambah, mengubah, } \\
\text { menghapus soal dan } \\
\text { jawaban }\end{array}$ \\
\hline KF-07 & Membuat User Login & Menambah User Login \\
\hline KF-08 & $\begin{array}{l}\text { Mengubah Password } \\
\text { Pengguna }\end{array}$ & $\begin{array}{l}\text { Mengubah Password } \\
\text { Pengguna }\end{array}$ \\
\hline KF-09 & Membuat Jadwal Ujian & $\begin{array}{l}\text { Menambah, mengubah, } \\
\text { menghapus Jadwal }\end{array}$ \\
\hline KF-10 & Mendaftarkan Peserta Ujian & Menambah Peserta Ujian \\
\hline KF-11 & Mengerjakan Soal & Mengubah Jawaban Soal \\
\hline KF-12 & Menampilkan Nilai Test & Menampilkan Nilai Test \\
\hline KF-13 & Menampilkan Riwayat Test & Menampilkan Riwayat Test \\
\hline
\end{tabular}

Fungsi sistem Paperless Test System pada tabel di atas, tidak semua dilakukan oleh Guru. Pada peran Guru fungsi sistem yang aktifkan hanyalah Mengubah Password 
untuk pengguna masing-masing, Melakukan Pengelolaan Pokok Bahasan, Membuat Soal dan Jawaban Test, Membuat Jadwal Ujian, Mendaftarkan Peserta Ujian dan Menampilkan Riwayat Test. Username guru dibentuk berdasarkan kode guru / NUPTK sedangkan password dibuat oleh sistem secara default. Dan dibagikan ketika pelatihan IbM berlangsung.

Kegiatan IbM dimulai dengan sambutan dari Kepala Madrasah (KaMad) MA Al Hadi, lalu dilanjutkan dengan sambutan dan perkenalan dari Tim Abdimas sekaligus memperkenalkan konsep Ujian Tanpa Kertas (Paperless Test System) dimulai dari cara mengakses sistem menggunakan web browser, cara melakukan login user, dan mengganti profil user (termasuk password login).

Pada Paperless Test System terdapat tiga peran pengguna yaitu Admin, Siswa dan Guru yang ditunjukkan pada gambar 2 halaman login pengguna. Pada pelatihan, guruguru Madrasah Aliyah Al Hadi diarahkan untuk memilih peran Guru dengan username dan password yang telah diberikan.

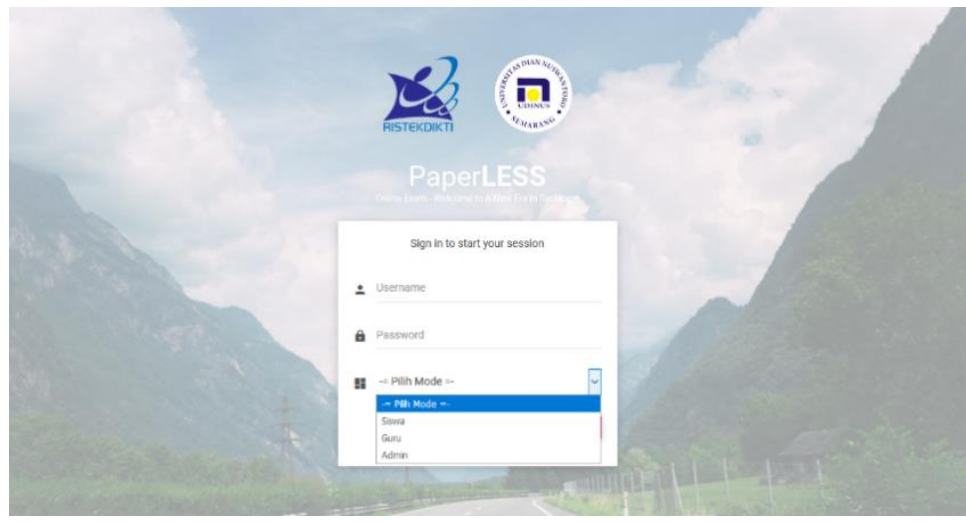

Gambar 2 Halaman Login Pengguna

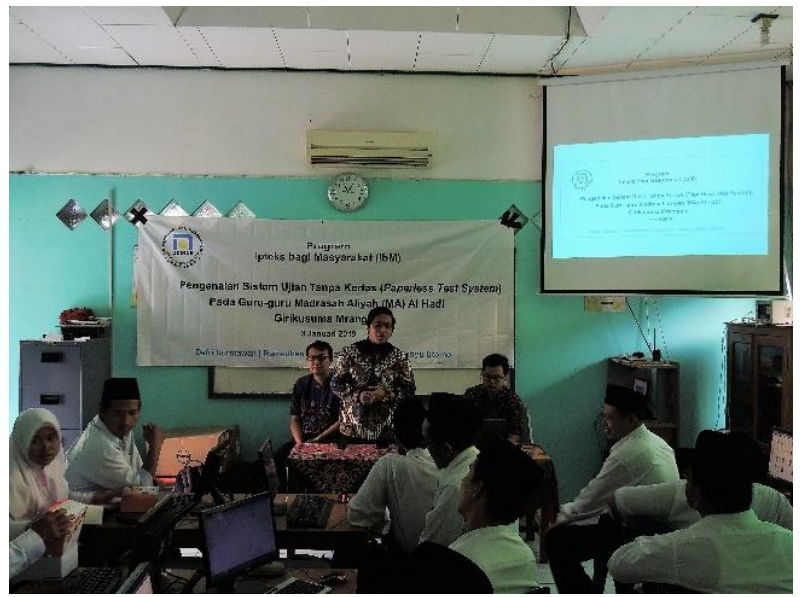

Gambar 3 Penyampaian Materi Pertama

Materi kedua praktek penggunaan Paperless Test System meliputi pengelolaan pokok bahasan dan pengelolaan soal. Pokok bahasan diisi sebagai label kategori pada soal yang akan dibuat. 


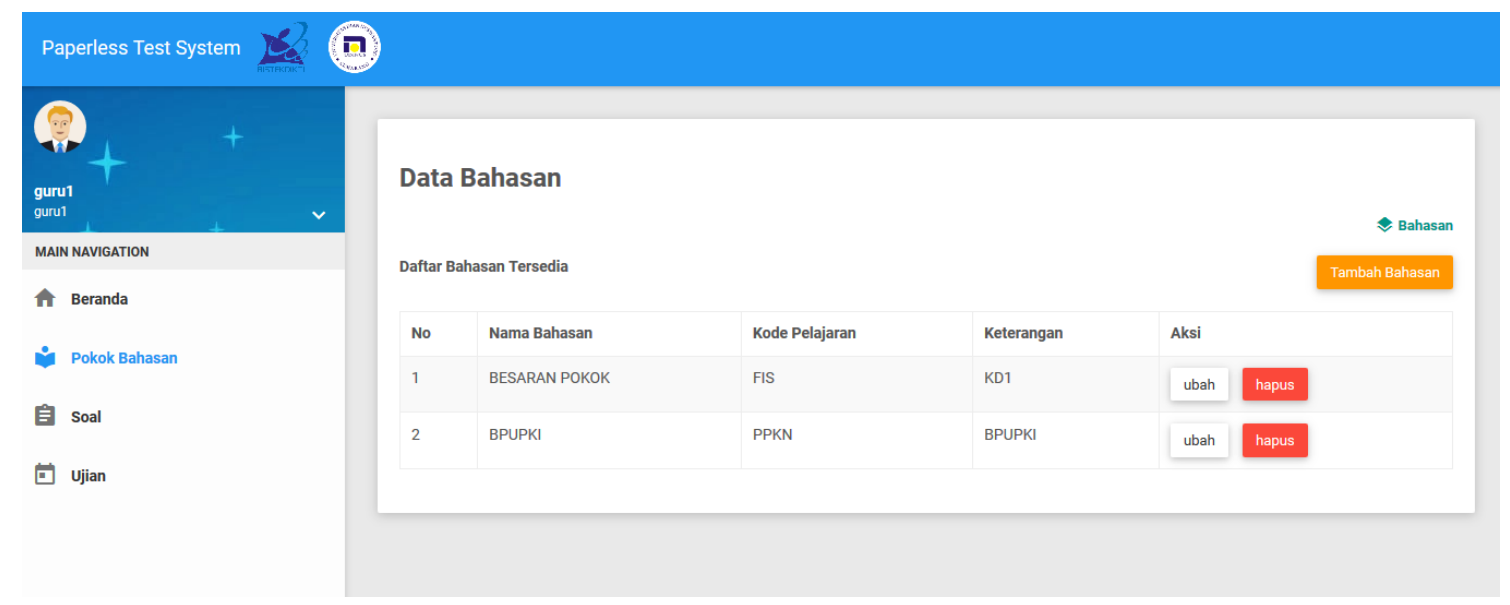

Gambar 4 Halaman Pokok Bahasan

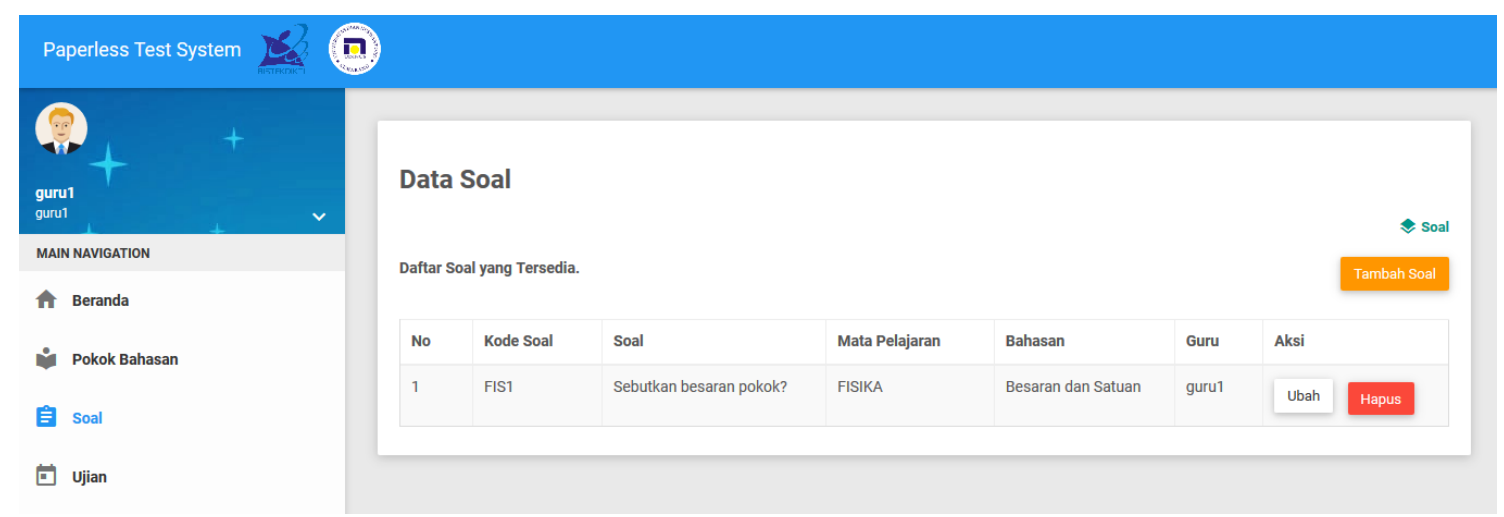

\section{Gambar 5 Halaman Data Soal}

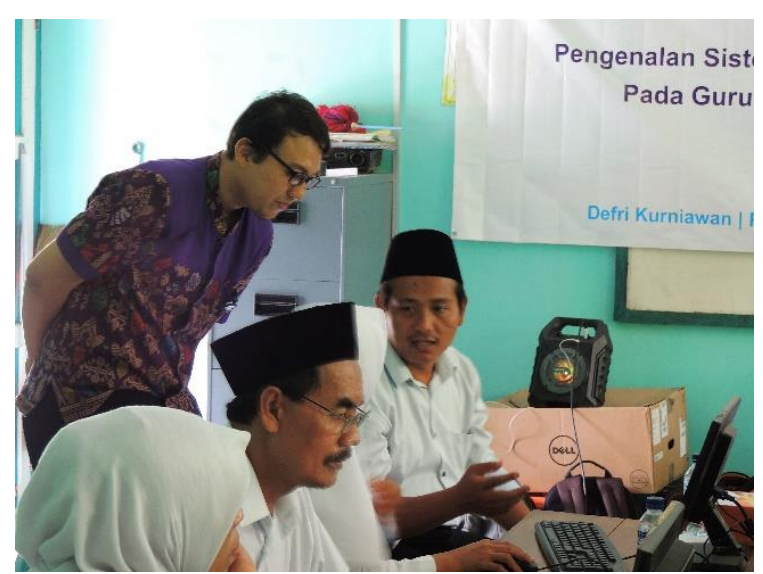

Gambar 6 Pembuatan Bank Soal Pada Materi Kedua

Pada materi ketiga, guru-guru MA Al Hadi diajak untuk melakukan simulasi mengerjakan ujian terhadap soal-soal yang telah diinputkan sebelumnya. Selain memberikan simulasi mengerjakan ujian, materi lain meliputi pembuatan jadwal ujian, mendaftarkan peserta ujian dan mengetahui riwayat ujian dipraktekkan sehingga guruguru mendapatkan pemahaman mengenai jalannya sistem secara utuh.

Guru-guru MA Al Hadi diberikan 5 (lima) user siswa untuk simulasi ujian, diharapkan dengan adanya simulasi menggunakan user siswa, guru-guru yang dilatih 
dapat memberikan pemahamannya dan mempraktekkan penggunaannya pada siswasiswa di kelasnya. Pada menu Ujian user Siswa, terdapat Aksi Terkerjakan yang berarti siswa tersebut sudah mengerjakan dan Kerjakan yang berarti adanya latihan ujian yang perlu dikerjakan. Setelah menekan tombol Kerjakan, maka sistem akan menampilkan halaman petunjuk pengerjaan soal. Jika Mulai Ujian ditekan maka sistem akan menampilkan daftar soal yang dikerjakan dengan durasi waktu (timer). Jika telah selesai menyelesaikan soal, sistem akan menghitung jumlah benar, salah dan nilai serta menyimpannya pada Riwayat Ujian.

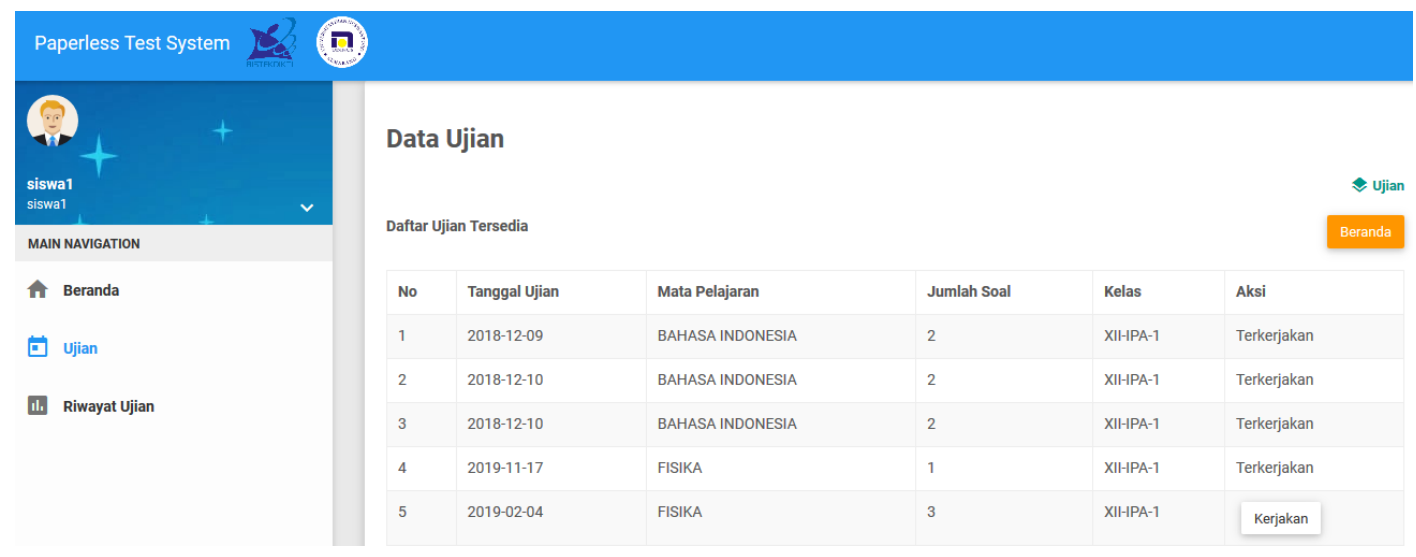

Gambar 7 Data Ujian Siswa

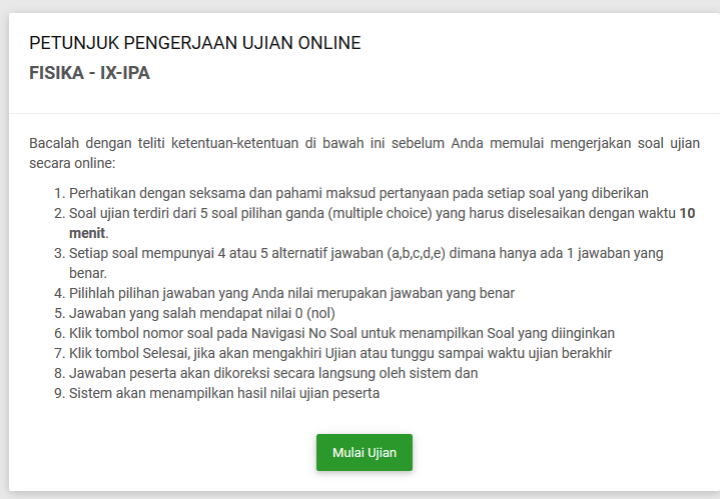

Waktu Ujian : 09:52

FISIKA - IX-IPA

1. Sebuah penghantar lurus panjang dialiri arus $2 \mathrm{~A}$ seperti tampak pada gambar disamping. Besar dan arah induksi magnet di titik $P$ adalah ... ( $20=4$ ? $\times 10-7 \mathrm{~Wb} / \mathrm{Am})$

a. $\bigcirc 8 \times 10.5$ t, masuk bidang kertas

b. $\bigcirc 6 \times 10-5$, keluar bidang kertas

c. $\bigcirc 4 \times 10-5 \mathrm{~T}$, masuk bidang kertas

d. $O 2 \times 10-5$ t, keluar bidang kertas

e. $O 1 \times 10-5 \mathrm{~T}$, masuk bidang kertas

2 Kawat $L$ dan $M$ sejajar berarus listrik seperti pada gambar!

a. $\mathrm{O} 48 \times 10.7 \mathrm{~N} / \mathrm{m}$ tolak menolak

b. $O 24 \times 10-7 \mathrm{~N} / \mathrm{m}$ tarik menarik

c. $\mathrm{O} 48 \times 10.6 \mathrm{~N} / \mathrm{m}$ tarik menarik

d. $\bigcirc 36 \times 10-6 \mathrm{~N} / \mathrm{m}$ tolak menolak

e. $\mathrm{O} 48 \times 10-4 \mathrm{~N} / \mathrm{m}$ tolak menolak

Gambar 8 Petunjuk Pengerjaan Ujian dan Daftar Soal Ujian

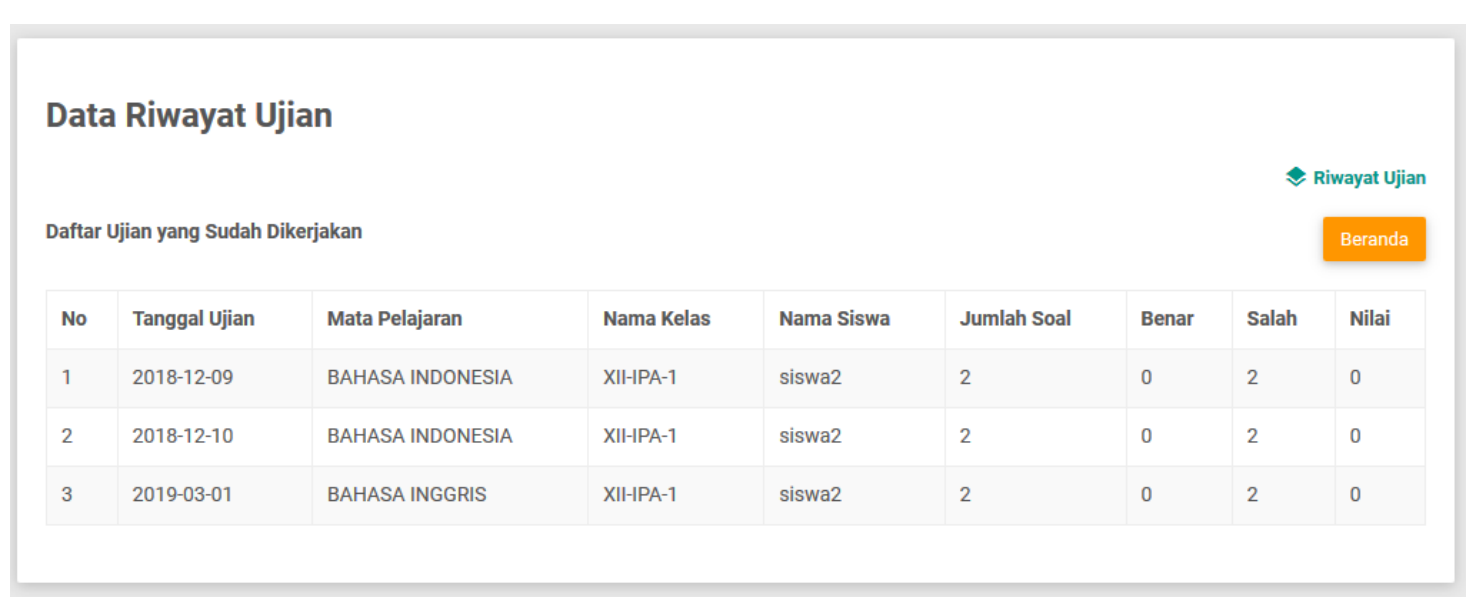

Gambar 9 Data Riwayat Ujian Siswa 


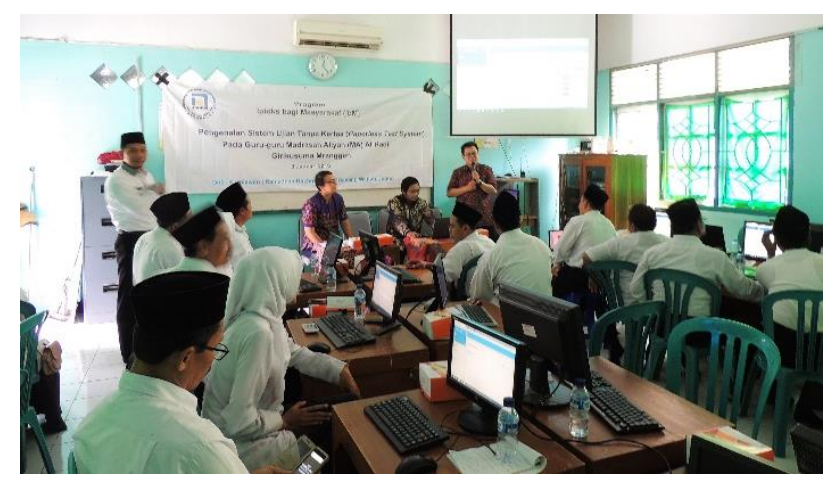

Gambar 10 Simulasi Mengerjakan Ujian Pada Materi Ketiga

\section{KESIMPULAN}

Kegiatan Ipteks bagi Masyarakat (IBM) dalam bentuk pelatihan pengenalan dan pendampingan penggunaan sistem ujian berbasis komputer secara online pada guruguru Madrasah Aliyah Al Hadi, Girikusuma, Mranggen dapat berjalan dengan lancar. Pelatihan memberikan manfaat berupa pengetahuan dan skill dalam menggunakan aplikasi berbasis web yang dapat digunakan oleh para guru pengampu dalam mengevaluasi penyerapan materi ajar para siswa di kelas.

\section{SARAN}

Pada kesempatan mendatang perlu adanya pengenalan sistem ujian berbasis komputer secara online kepada para siswa di Madrasah Aliyah Al Hadi, sehingga sistem dapat diterapkan sepenuhnya dalam mempersiapkan Ujian Nasional Berbasis Komputer. Fitur aplikasi Paperless Test System juga perlu diperbaharui, terutama pada fitur evaluasi hasil ujian yang dapat dievaluasi berdasarkan pokok bahasan / kemampuan dasar para siswa, sehingga dapat diketahui pokok bahasan mana dari siswa tersebut yang perlu ditinggkatkan.

\section{DAFTAR PUSTAKA}

[1] Prosedur Operasional Standar Penyelenggaraan Ujian Nasioanl, Jakarta: Badan Standar Nasional Pendidikan (BSNP), 2015.

[2] R. Pakpahan, "Model Ujian Nasional Berbasis Komputer: Manfaat dan Tantangan," Jurnal Pendidikan dan Kebudayaan, vol. 1, no. 1, pp. 19-35, 2016.

[3] R. Arief dan E. Suryani, "Sistem Dinamik Ujian Nasional Berbasis Komputer Untuk Meminimalkan Resiko Kecurangan Serta Meningkatkan Efektifitas Dan Efisiensi Anggaran," Integer Journal, vol. 1, no. 2, pp. 67-75, 2016.

[4] K. "kemdikbud.go.id," 2018. [Online]. Available: https://puspendik.kemdikbud.go.id/hasilun/. [Accessed 410 2018].

[5] E. Yulia, R. dan M. Nasir, "Hubungan antara Hasil Uji Kognitif Try Out Ujian Nasional (UN) dengan Hasil Ujian Nasional (UN) Mata Pelajaran Kimia SMA Kota Banda Aceh Tahun Ajaran 2014/2015," Jurnal Ilmiah Mahasiswa Pendidikan Kimia (JIMPK), vol. 1, no. 3, pp. 35-42, 2016.

[6] F. Narimo, B. and M. Sapti, "HUBUNGAN NILAI TRY OUT TERHADAP NILAI UJIAN NASIONAL MATA PELAJARAN MATEMATIKA SISWA SMP DI KECAMATAN 
SAPURAN," Ekuivalen, vol. 9, no. 1, pp. 38-44, 2014.

[7] R. R. Sani and D. Kurniawan, "Analysis And Design Of Online Exam System At School Using Unified Model," in ISRITI, Yogyakarta, 2018.

[8] R. R. Sani and D. Kurniawan, "Rancang Bangun Sistem Try Out Berbasis Paperless Untuk Evaluasi Hasil Belajar Siswa Dengan MVC," Jurnal Teknologi Informasi dan Ilmu Komputer (JTIIK), vol. 6, no. 3, pp. 277-286, 2019. 